TITLE:

\title{
Quandle coloring conditions and zeros of the Alexander polynomials of Montesinos links(Abstract_要旨 )
}

$\operatorname{AUTHOR}(\mathrm{S})$ :

Ishikawa, Katsumi

\section{CITATION:}

Ishikawa, Katsumi. Quandle coloring conditions and zeros of the Alexander polynomials of Montesinos links. 京都大学, 2019, 博士(理学)

ISSUE DATE:

2019-03-25

URL:

https://doi.org/10.14989/doctor.k21536

\section{RIGHT:}

許諾条件により本文は2019-11-09に公開; Journal of Knot Theory and Its Ramificationsに掲載予定。ウェブページ上には掲載済み。 https://www.worldscientific.com/doi/10.1142/S0218216518500803 DOI:10.1142/S0218216518500803 
( 続紙 1 )

\begin{tabular}{|l|l|l|l|}
\hline 京都大学 & \multicolumn{1}{|c|}{ 士博 ( 理 学 $)$} & 氏名 & 石川 勝巳 \\
\hline 論文題目 & $\begin{array}{l}\text { Quandle coloring conditions and zeros of the Alexander polynomials } \\
\text { of Montesinos links } \\
\text { (カンドル彩色条件とモンテシノス絡み目のアレキサンダー多項式の零 } \\
\text { 点) }\end{array}$ \\
\hline
\end{tabular}

(論文内容の要旨)

円周を 3 次元球面に埋め込んだ像を結び目という。円周の排反和を 3 次元球面に埋 め込んだ像を絡み目という。結び目を 3 次元ユークリッド空間の中にあるとみなし て、平面に射影した射影図の各交点に上下の情報をつけたものを結び目図式という。 結び目図式を結び目のひもにそってたどったときに交点の上下が交互に現れるような 図式を交代図式という。交代図式を結び目図式としてもつような結び目を交代結び目 という。3 次元球体に 2 つ弧を自明に埋め込んで得られるタングルを自明 $(2,2)$ タ ングルといい、自明 $(2,2)$ タングルと同相なタングル（すなわち、自明 $(2,2)$ タングル に 4 次の組みひもを結合して得られるタングル）を有理タングルという。有理タング ルを直列的に結合して得られる絡み目をモンテシノス絡み目という。また、結び目の 補空間の無限巡回被覆空間の 1 次ホモロジー群の表示行列の行列式をアレキサンダー 多項式という。2002年にホストは、多くの計算機実験にもとづいて、交代結び目のア レキサンダー多項式の零点の実部は $(-1)$ 以上であることを予想した（ホスト予想）。 また、カンドルとは、群において群演算を忘れて「共役をとる」という操作を演算と して残すことによって得られる公理で定められる代数系である。とくに、群の共役類 には自然にカンドルの構造がはいり、これがカンドルの典型的な例である。結び目の 補空間の基本群は、結び目図式から自然に定められる群表示をもつが、この群表示か ら自然に構成されるカンドルを結び目カンドルという。結び目カンドルからカンドル Xへのカンドル準同型を、その結び目のX彩色という。

本論文において申請者は、カンドルを用いてモンテシノス絡み目のアレキサンダー 多項式の零点について研究した。とくに、モンテシノス絡み目の特別な場合のある種 のプレッツェル絡み目に対してホスト予想が成立することを証明した。また、ある種 のモンテシノス絡み目として、ホスト予想に無限個の反例が存在することを証明し た。0でない複素数比対して、複素数平面に自然にアレキサンダーカンドルの構造を 入れることができて、このカンドルを $\mathrm{C}_{\mathrm{t}}$ とかくことにする。結び目のアレキサンダー 多項式が堭零にもつとき、この結び目は非自明な $\mathrm{C}_{\mathrm{t}}$ 彩色をもつことが知られてい る。また、このとき、その $\mathrm{C}_{\mathrm{t}}$ 彩色を結び目図式の弧に $\mathrm{C}_{\mathrm{t}}$ の元を対応させることにより 表示することができて、非自明な $\mathrm{C}_{\mathrm{t}}$ 彩色が存在するかどうかという問題は複素数平面 上に適切な性質をみたす点配置が存在するかどうか、という問題に帰着される。この 場合の「適切な配置」とは、結び目図式の各交点に対して、上道の弧に対応する点を 原点としたとすると 2 つ下道の弧に対応する 2 つの点の位置が倍の位置になって いる（すなわち、その 3 点が上道の弧に対応する点に関して一定の角を定める）とい う条件である。交代結び目の交代図式に対しては、図式の弧の対応する点は常にその ような角の頂角をつくることになり、そのような点配置には強い制限がはいることに なる。この事実を用いてアレキサンダー多項式の零点の值を調べるという手法は申請 者のアイデアであり、申請者はこのアイデアの手法によりホスト予想にアプローチし て、多くの結び目に対してホスト予想を証明し、また、反例の存在も証明した。 
(続紙 2)

(論文審査の結果の要旨)

アレキサンダー多項式は結び目の古典的な不変量であり、1920年代にアレキサン ダーによって導入されて、それ以来多くの研究がなされてきた。前述のように、アレ キサンダー多項式は、結び目補空間の無限巡回被覆空間の 1 次ホモロジー群の表示行 列の行列式として定義される。さらに、アレキサンダー多項式には、様々な同值な定 義も知られており、たとえば、結び目補空間の基本群の群表示の関係式をフォックス 微分することによって構成される行列の行列式として定義することもでき、また、 リー環 $\mathrm{Sl}_{2}$ の量子群の 1 のべき根における表現に対応する量子不変量として定義するこ ともできる。すなわち、アレキサンダー多項式は、低次元トポロジーや量子トポロ ジーの様々なトピックと関連しており、基本的で重要な不変量である。従来の研究 で、アレキサンダー多項式の様々な性質についても研究がなされてきていて、とく に、アレキサンダー多項式の零点についても多くの研究がなされてきた。アレキサン ダー多項式の零点の解釈について、結び目補空間の基本群の $\mathrm{C} \times$ 表現の空間を考える と、この表現がさらに大きいリー群の表現に変形可能であるための条件が、アレキサ ンダー多項式の零点で与えられる、ということが、アレキサンダー多項式の零点の 1 つの位相幾何学的な解釈である。

本論文において、申請者はモンテシノス絡み目のアレキサンダー多項式の零点につ いて研究している。アレキサンダー多項式の零点 $\mathrm{t}$ 解釈は、前述のように、結び目 図式が非自明な $\mathrm{C}_{\mathrm{t}}$ 彩色をもつことである、と上述の解釈を言い換えることができて、 この問題は、複素数平面上に（前述の）適切な性質をみたす点配置が存在するかどう か、という問題に帰着され、前述のように、とくに交代結び目の交代図式に対して は、そのような点配置には強い制限がはいることになる。この事実を用いてアレキサ ンダー多項式の零点の值を調べるという手法は申請者のアイデアであり、秀逸なアイ デアである。申請者はこのアイデアの手法によりホスト予想にアプローチして、プ レッツェル絡み目に対してホスト予想が成立することを証明し、また、ある種のモン テシノス絡み目としてホスト予想に無限個の反例が存在することを証明した。ホスト 予想は非常に多くの（数万個以上の）交代結び目に対して成立することが計算機実験 により確かめられていて多くの専門家はこの予想が成立することを信じていたので、 申請者のこの結果は非常に衝撃的な結果である。申請者は、その後、平澤美可三氏 （名古屋工業大）と鈴木正明氏（明治大）との共同研究で、彼の反例存在の証明の方 針にもとづいて、ホスト予想の具体的な反例を構成しているが、この反例は、交点数 が700以上ありそのアレキサンダー多項式のある零点の実部が $-1.000265 \ldots$. . であよ うな結び目で、彼の反例存在の証明がなければとうてい発見はできなかったとおもわ れる例である。彼のこの研究は専門家には非常に高く評価されている。

よって、本論文は博士 (理学) の学位論文として価值あるものと認める。また、平 成 31 年 1 月 4 日、論文内容とそれに関連した事項について試問を行った結果、合格 と認めた。

要旨公表可能日：即日 